\title{
TITHING IN UGARIT AND THE PENTATEUCH - POSSIBLE IMPLICATIONS FOR AFRICA
}

\author{
Miracle Ajah \\ Stellenbosch University
}

\begin{abstract}
The thesis of this paper is stating that a rigorous study and theological interpretations of the different examples of tithing in Ugarit and the Pentateuch can motivate a more reflected theological-ethical understanding and the practice of tithing amongst believing communities in Africa. The tithe demanded that the people serve their God at a significant cost to themselves. An appeal is made to the Church in Africa to consider how to mobilize support for her projects through the application of their theological-ethical understanding of tithing.
\end{abstract}

Key Words: Tithe, Ugarit, Pentateuch, and Theological-ethical interpretation

\section{Introduction}

In an era when many African countries have extricated themselves from the shackles of colonialism and imperialism, many churches in Africa (especially the ones planted by Western missionaries) are yet to be disentangled from the economic and psychological enslavements to European and American churches. ${ }^{1}$ Most of these churches can not fund their programmes and accept assistance which comes from Europe or America. This dependent syndrome has robbed the African church of her prestige and has affected her psyche in adopting a self-supporting and a self-propagating programme, thereby adopting all kinds of fund raising techniques in the name of church funding. The African problem is usually attributed to poverty, but I beg to differ in this paper. According to New African Magazine (Sept/Aug 2005:15), "Nigeria's Anti-Corruption Commission estimated in June this year that about $\$ 521$ bn had been stolen from the Country and stashed in Western Banks between 1960 and 1999." It is impossible for a poverty-ridden country to have such amount stolen, besides other wastages, and still function effectively as Nigeria is doing today. The perpetrators of these robberies were the so-called Christians and Muslims. Every country in Africa has enough human and natural resources to sustain her. In Ghandi's words, "There is enough in the world to satisfy our need but not enough to satisfy our greed (http://www.justiceafrica.org/postcard060105.htm). Corrupt leadership and mismanagement are the key problems in Africa. So, the church funding problem in Africa is a complex ideological problem, which emanates from (to name but a few) moral, cultural, psychological and economic orientations.

This paper is on "Tithing in Ugarit and the Pentateuch - possible implications for Africa." Tithing is a type of giving and a custom that dates back to the Old Testament times and adopted today by many Christian denominations. In this practice members are expected to contribute 10 percent of their regular income for church projects and maintenance of the church workers. In the Old Testament, there was no clear distinction between secular and sacred in Israel's nationalism. So tithing was one of the major means of upholding that

I do not mean that fraternal relationship is wrong, but that partnership and not paternity should be the watchword. 
nationalism both economically and spiritually. The thesis of this paper is stating that a rigorous study and theological interpretation of the different examples of tithing in Ugarit and the Pentateuch can motivate a more reflected theological-ethical understanding and the practice of tithing amongst believing communities in Africa. It is our theology that shapes our ideology in Africa. The African theology must be thoroughly reflected if the church is to see the light of the day. Consequently, the Church in Africa should consider how to mobilize support for her projects through the application of their theological-ethical understanding of tithing in the Pentateuch. The moment the African ideology towards giving is improved theologically, it will be confirmed that poverty is not the factor militating against church funding.

\section{Tithing Texts from Ugarit (ca. $14^{\text {th }}-13^{\text {th }}$ Centuries BCE)}

The ancient citystate of Ugarit is a valuable resource to biblical studies and historical archaeology. Excavations done at Ras Shamrah in Ugarit brought to light the most detailed body of material of the "Canaanite" culture which the Israelite tribes met in the "Promised Land" at the time of conquest. Dahood reported that excavations of 1929 brought to light clay tablets and fragments of religious texts, letters, diplomatic materials, etc, which contained myths and legends of the Canaanites of the $2^{\text {nd }}$ millennium BCE, and that helped to formulate the ethical ideals and the religious beliefs of the pre-Biblical Canaanites (NCE 2003:267). Ugarit was so significant in the sense that the language was similar to Hebrew; some of the names and deities found in the Bible are found in its texts, for example the god Baal and Dagon. Ugarit was geographically closer to the land occupied by the Israelites than the other great centres of ancient Near Eastern civilization (Watson \& Wyatt 1999:1). It was an important strategic and commercial centre, standing at the "cross roads" of major land and sea routes, and was doubtless quite cosmopolitan (Pardee 1992:698).

In Ugarit, the tithe was viewed from the perspective of a whole village as a unit. There is never a mention of an individual villager paying a tithe. The king of Ugarit was the sole recipient of the tithes, which he distributed to any of his officials called "men of the king". Tithes were not exclusively for the priests or temple staff. Their portion came as a grant from the king. They were treated the same as other specialists in regard to tithes, a reflection of the royal and administrative control of the temples. It is recorded in PRU III $16.153^{2}$ (a legal text):

From the present day on, Ammistamru, ${ }^{3}$ son of Niqmepa, king of Ugarit has given to

Yasiranu, son of Husanu, the village (alu) E[-]ish with everything it has forever, (also) to his sons and grandsons, its grain, its beer (sikaru) of its (the village's) tithe (ma 'sharu),

and the sheep - the pasturing tax (ma-aq-qa-du) shall be for Yasiranu. The silver of the

gifts and the silver of the bridegroom's friend and service boys (su-sa-pi-in-nu-ti) shall

be for Yasiranu"(COS III 2002:258; cf. Fisher 1975:95).

So in Ugarit the tithe was a royal tax which the king exacted for himself and for the benefit of his officials. The temples or their staff could not lay claims on the tithes because they were assigned by the king. The king could donate an entire village to his family members

\footnotetext{
ma'sharu (Tithe/ village tithe); Recipient = the king of Ugarit/ The king to his official; The Giver $=$ The whole village as a unit; Goods subject to tithe = Property, produce and currency; Motivation/context = A royal tax to the king, Slave labour, and No theological motivation.

3 Ammistamru II reigned ca. 1260-1225 BCE (COS III 2002:258)
} 
without the interference of the temple. An example is recorded in PRU III 16.276 (a legal text):

From the present day Niqmadu, ${ }^{5}$ son of Ammistamru king of Ugarit gave (donated) the village Uhnappu to Kar-Kushuh, son of Ana[nu] and to Apapa, the king's daughter, with its tithe ('shr) with its custom-duties (miksu). Nobody shall raise claims concerning Uhnappu against Kar-Kushuh and Apapa and against the sons of Apapa. He (the king) donated Uhnappu. Further: Kar-Kushuh is pure like the sun forever. Later he is (also) pure. The temple of $\mathrm{Ba}^{\prime} \mathrm{al}$ of the Hazi mountain and its priests shall not have claims to Kar-Kushuh (COS III 2002:201).

In another context, tithes were offered to Baal to repel an enemy attack. The offerer partook of it in a sacrificial banquet. It is found in a religious text from Ugarit (KTU 1.119:2635//RS 24.266; Olmo Lete 1999:304,305). ${ }^{6}$ This passage falls within the sacrificial liturgy and psalmody of Ugarit. It was recited on the occasion of national crisis, probably as the culmination of a ritual in which the king offers sacrifices to the gods and to his "heroic" ancestors in the urban sanctuaries. The king of the land was the chief celebrant. It is an example of a votive prayer directed to Baal. This cultic royal function is carried out in the city temples of $I l u$ and $B a$ ' $l u$ after the king has sacralized himself (KTU 1.119:12-14). The tithe in this context was used for a ritual banquet of the community, used to invoke the favour of the deity to defend the land.

The type of tithing practiced in Ugarit contributed to the number of problems they had. The villages existed for the king's benefit. In a way they were captives in their own land, being subjected to debt-slavery or becoming fugitives. Liverani (1988:938) reported how they were deprived culturally, technologically and excluded from any political decisions. The oppression they suffered could account for their lack of solidarity for the palace in time of war, which serves to explain how the Canaanite cities, similarly organized, could be quickly overcome by the Israelites. Samuel's denunciation of Kingship in 1 Sam. 8:4-17 is rooted in this Ugarit experience (see Mendelsohn 1956:17-22). It is interesting to note that the same concept of tithing was taught, commanded and applied in the Pentateuch in a more productive and inclusive manner with a theological orientation. Samuel did not denounce tithing but the institution of kingship. A survey of the tithing texts in Pentateuch will show why and how it was the most productive resource for ancient Israel's religious institution.

\section{Tithing Texts from Pentateuch}

In examining the various references to tithing in the Pentateuch, we shall identify the recipients of tithes, who had to pay these tithes, the motivations for the payment, whether it was obligatory or voluntary and the goods subject to tithing.

a) Gen 14:17-24. ${ }^{7}$ Abram led the battle to defeat the northern kings and returned everything and everyone to the land of Canaan. Melchizedek king of Salem and priest

$4 \quad$ 'eshr (Tithe/ one- tenth); Recipient = The king of Ugarit/ The king to a family member; The Giver = The whole village as a unit; Goods = Property, produce and currency; Motivation/context = A royal tax to the king, Slave labour, and No theological motivation.

5 Niqmaddu III reigned ca. 1225/1220-1215 BCE (COS III 2002:201).

$6 \quad$ eshretu $($ Tithe/ banquet/ feast); Recipient $=$ Baal, the patron deity of the Ugarit; The Giver $=$ The whole village as a unit presided by the king of Ugarit; Goods = Grain, wine and oil, etc; Motivation = For Baal to repel an enemy's attack.

7 מעשטר (Tithe/tenth part/one-tenth); paid to Melchizedek; by Abraham; the goods subject to tithing were War booty; and the motivation/context was A tribute to the royal sanctuary. 
of God Most High brought him food and drink and blessed Abram. Abram gave him one-tenth of everything. The recipient of tithes in this text was Melchizedek ${ }^{8}$ because of his position as the king of Salem and the priest of God Most High. Abram was the payer, and his motivation for payment could probably be an acknowledgement that his victory came from אִ עֶלילין ('el'elyon - God Most High), and a recognition that Melchizedek was the priest of אל עִ עיריון (1981:203) argues, "The question whether the subject of ויתן-לו (and he gave to him) is Melchizedek or Abraham is to be answered from the structure of the whole, which is a cultic exchange." He maintains that Abram acknowledged the priestly dignity of Melchizedek the king by giving him the tithe. The tithe in Genesis is portrayed as a tribute to a king, a practice found in Ugarit.

(b) Genesis 28:18-22. ${ }^{9}$ Jacob vowed to God that if God would protect and provide for him on his journey away from home, that he would give back to God, as a sign of worship, a tenth of all God would prosper him with. He erected a pillar of stones as a memorial and called the place where he would fulfil the vow ביתדיאל (Bethel). We agree with NM Sarna (1989:200) when he said that the structure and style of Jacob's vow is in accord with a pattern of vows in the Old Testament (see Judges 11:30-31 - Jephthah; I Sam 1:11 - Hannah; 2 Sam 15:8 - Absalom). The speaker promises to do certain things for God, if God responds in his/her favour. But, Jacob's vow is unique because all that he desired had been unconditionally promised by God in Genesis 28.15. The tithe here is seen as a votive offering.

(c) Leviticus 27:30-33. ${ }^{10}$ The text is a declaration that a tenth part of both "seed from the

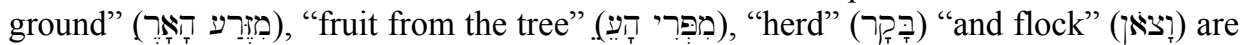

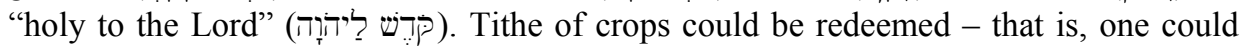
substitute something else in payment - if one is willing to add a fifth to its value. ${ }^{11}$ The tithe from the herd or the flock could not be redeemed. The goods subject to tithe in this text were seed from the ground, fruit from the tree, herd and flock. The precise method on how the animals for the tithe were determined is not elaborate. The text suggests that the increment of a flock or a herd was passed through a line and every tenth member was pointed out by a shepherd's staff, and then marked for dedication to the sanctuary. JE Hartley (1992:485) reports that one way of marking animal in antiquity was the use of a coloured dye to make a stripe across their backs (cf. Jer. 33.13; Ezek. 20:37). The Leviticus tithe is more of a tax than an ordinary offering.

(d) Numbers 18: 21-32. ${ }^{12}$ The Levitical right to tithes is set out in vv 21-24 and a priestly right to tithes from Levites in vv 25-32. The Levites were to receive the tithes in return

8 Melchizedek held a dual post of a "king" and "priest". Tithing to both God and king was well known in the Ancient Near East (Averbeck 1997:1037; cf. Jagersma 1981:120).

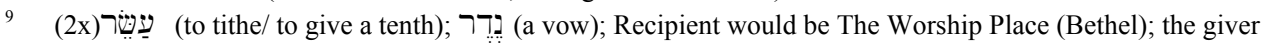
was Jacob; goods subject to tithing = Goods obtained in the course of a commercial expedition; motivation/context $=$ A votive offering.

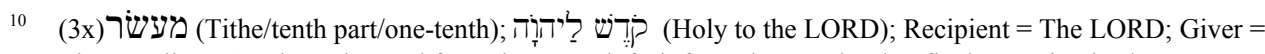
The Israelites; Goods = The seed from the ground, fruit from the tree, herd \& flock.; Motivation/context = A Tax to the Sovereign owner of land, the Lord.

11 In the Ancient Near East, Babylonian and Assyrian tithes of produce were commutable but not of animals, just like Lev 27: 31-33.

12 (6x) כישעטכר (As a wage -not as a mere perquisite or donationv.8); The recipient = The Levite (Tithe of tithes to the Priest); the Giver = The Israelites and the 
for their service in the tent of meeting. Among the Israelites they had no allotments like the other tribes. They, in turn were to set apart one-tenth of the tithes (the best of all of them), which they received as an offering to the Lord which will be received by the priests as represented by Aaron. Subsequently, they were free to retain the nine-tenth to themselves. The tithes were to be eaten in any place by the Levites and their households. Numbers regards the payment of tithes as an obligation and a part of fulfilling God's laws, who is the sovereign owner of the Promised Land. Tithing in numbers was portrayed as wage and not as a donation.

(e) Deut $12: 1-19 .{ }^{13}$ In this text, tithing was one of the statutes and ordinances the children of Israel had to diligently observe when they occupied the "Promised Land." The tithe was to be taken to the place where the Lord would cause the Lord's name to dwell (vv. $5,11,18)$. The household of the payer (vv.12,17, 18) should not eat it in any place he sees, but at the chosen place with joy; the Levites were to partake of it since they had no allotment or inheritance with the people (vv.12, 18, 19). The goods subject to tithe were grain, wine, and oil (v.17).

(f) Deut 14:22-29. ${ }^{14}$ This law prescribes the setting aside of a tithe of all the yield of the seed from the field. The tithe is to be brought in anually and eaten at the place chosen by God, (a symbol of dwelling for the Lord's name). If the distance is far, the tithe may be converted to money and brought to the chosen place to be spent on festive meal, to be eaten by the payer's household. Every third and sixth year of each sabbatical cycle, the tithe will be kept in the local stores, for the benefit of the Levite, who has no land of his own, the resident alien, the fatherless, and the widow. The people were to pay the tithes so that "the Lord your God may bless you in all the work that you undertake" (14.29). The goods subject to tithe were grain, wine, and oil (v.23).

(g) Deut 26:12-15. ${ }^{15}$ Here, the law prescribes what the Israelites should do after they have fulfilled the law of tithing on the third year, referred to as the year of tithing. The tither would proclaim that he had given out the tithe to the Levites, the resident aliens, the fatherless and the widows, and not desecrated it by using it for impure purposes. The tither would then petition the Lord: "Look down from your holy habitation, from heaven, and bless your people Israel and the ground that you have given to us, as you swore to our ancestors - a land flowing with milk and honey" (v.15). The Deuteronomic sources present the tithe in the context of a communal meal and as impost for both the Levites and the less privileged in the society.

Levites (cf. Heb 7:4-10); Goods = The grain from the threshing floor and the produce from the wine press; Motivation/context $=$ A wage in return for the services done for the Lord.

13 (3x) מעש: (The (The Place which the Lord shall choose); Recipient $=$ The Household of the payer and the Levite for a communal meal; The Giver $=$ The Israelites; Goods = Grain, wine, and oil (v.17); Motivation/context = Annual Obligation and Communal meal.

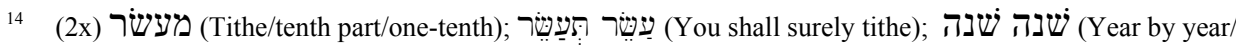
annually/ yearly); Recipient = The payer's household, The Levite, the Stranger, the orphan and the Widow; The Giver = The Israelites; Goods = Produce of the field: Grain, wine, and oil (v.22, 23), can be converted in money; Motivation/context $=$ Annual Obligation, Communal meal and Charity .

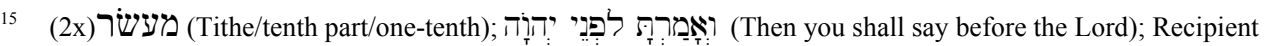
$=$ The Levite, Stranger, the Fatherless and the Widow; The Giver $=$ The Israelites; Goods $=$ Produce $($ Not specific); Motivation/context $=$ An Obligation, Charity. 


\section{Understanding the Pentateuchal References to Tithing}

A first glance at the various references to tithing in the Pentateuch as one common practice of the ancient Israel arouses a curious inquiry on how to account for the seeming irregularities and discrepancies found in them. Genesis 14:20 portrayed tithing as a tribute to the royal sanctuary, which Melchizedek represented; Gen 28:22 as a votive offering to the LORD's Sanctuary; Lev 27:30-33 as a tax to the Lord, the Sovereign owner of land; Num 18:21-32 as a wage (not a mere perquisite or a donation) in return for the services done in the tent of meeting of the Lord; and the references in Deuteronomy as an annual obligation related to a communal meal. The recipients and the methods of payment appear to be different. Goods subject to tithing varied.

In an attempt to explain the seeming irregularities and discrepancies, early Jewish tradition and some Christian tradition-historical criticisms have identified two or three different tithes in the Pentateuch. A first tithe consisted of the tithe to the Levites/tithe of tithes to the priests (Num 18; Deut 14:27). A second tithe from the remaining nine-tenths was set apart and eaten by the household of the payer (Deut 14:22-26; cf. Mish. Maaser sheni ii.1; Carpenter 1988:863). The third tithe was the tithe to the poor (Deut 14:28, 29; cf. Josephus Ant. 8.22:240-243). Scholars like J Wellhausen (1885/1994:156-59), SR Driver (1902:167-173), Guthrie (1962:654-655), have concluded that there was more than one basic tithe, and that the discrepancies in the documents arose because of historical evolution.

On the other hand, some recent studies believe that the tithe passages in the Pentateuch are not contradictory but complementary (McConville 1984:75-77; Averbeck 1997:10471049). In trying to reconcile the Deuteronomic tithe with the tithes in Leviticus and Numbers, Moshe Weinfeld (1971:1160) argued that the novelty of eating the tithe (in Deuteronomy) instead of giving it away to the cult and its staff (as in Leviticus and Numbers) could be explained against the background of the cultic reform, which abolished the provincial sanctuaries and their officials, and which stands at the basis of the Deuteronomic law code. Making reference to the reforms under Nehemiah (10:35-39; 12:44-13:12), McConville argued:

Nehemiah knew the legislation of Deuteronomy as well as of Numbers and Leviticus, yet represented only a single tithe. Here is what ought to be a final answer to the old Jewish solution. The idea of multiple tithes, having ancient Jewish tradition behind it, should not be lightly dismissed. But it fails because it is not the most ancient Jewish interpretation. That honour belongs to the book of Nehemiah, whose author knew all the relevant laws but only one tithe (McConville 1984:75).

The greatest problem facing ancient studies is the non-availability of coherent chronological data that would explain the form and function of certain events or concepts that took place in the remote past. The concept and practice of tithing in the Pentateuch is a prime example. While we extol the efforts made so far by scholars in explaining the seeming irregularities and discrepancies surrounding the concept of tithing, we must admit that to reconstruct a coherent picture of the history of tithing in Israel, through a literary or historical evolution, proves difficult and unsatisfactory. The quest for a coherent historical tithe system of ancient Israel may prove difficult, but it is possible to develop a satisfactory picture of the theological significance of the concept in the available texts. This paper will highlight some of the institution's theological significance and their implications to believing communities in Africa. 


\section{The Relevance of the Ugarit tithe to the Pentateuch}

The tithe in Ugarit is of direct relevance to the Pentateuch tithe, especially to its formulation and application in the Old Testament. In comparing the Ugarit documents with the Pentateuch, it is observed that (a) Tithing to both God and King was well known in Ugarit (Averbeck 1997:1037; cf. Jagersma 1981:120). ${ }^{16}$ The tithe in Gen 14 was a tribute to the royal sanctuary, which Melchizedek represented. Abram must have acted in accordance with the custom prevalent at this time. It was a good example of an individual paying tithe in the Old Testament, which contrasted the practice at Ugarit where tithes were viewed from the perspective of a whole village as a unit (Anderson 1987:79). Furthermore, temples in Ugarit in some instances received tithes of goods obtained in the course of a commercial expedition (Jagersma 1981:123). Jacob's vow was in line with that custom (Gen. 28:20-22). (b) In Ugarit the tithe was an obligation on the whole village. The Priestly and Deuteronomic documents in the Pentateuch gave a legalistic backing to it as a demand on every Israelite (Lev. 27:30-33; Num 18:21-32; Deut 14:22-29). (c) Just as the sacred and the secular were fused in Ugarit, the Pentateuch did not make any distinction. The command to tithe was both religious and political in the Pentateuch. (d) In a religious text from Ugarit, the tither partook of it in a sacrificial banquet; this depicts the provision of the Deuteronomic code (Deut 14:22-26; cf. Jagersma 1981:118). (e) In Ugarit the tithe was a royal tax which the king exacted for himself and for the benefit of his officials, and in the Pentateuch the tithe was a form of tax that was different from other forms of giving, which the LORD required them to bring for the maintenance of the cult and its staff. (f) The Pentateuch tithes were theologically motivated; it was not always so in Ugarit.

\section{Theological Significance of Tithing in the Pentateuch}

The payment of tithe in the Pentateuch is rooted in the belief that it was commanded by God, even though the instruction may have been communicated to the people by a king or a prophet. It is not clear why it was fixed at 10 percent (one-tenth). Probably it is connected with primitive views about numbers or with methods of counting, example by fingers and fives. It is also implied that an individual was left with a sufficient percentage of his income to care for his private needs, although it was assumed that some fractions out of the individual's portion could still be used as almsgiving or other voluntary gifts. In contrast with other forms of offerings and sacrifices, tithing was unique because it provided the most quantifiable measure of impost for the cult and its staff. According to Carpenter (1988:863), "By giving the tithe the people recognized the validity of the priests' and Levites' role as God's representatives and acknowledged their right to receive support for the spiritual service they performed on the people's behalf."

Furthermore, other offerings were referred to as a "perquisite, allotted portion or a donation" (משחה-Num 18:8), while tithe was specifically called a "wage, payment, or a reward" (שלכר - Num18:31), which the Levites were to receive as the proper compensation for their sanctuary labours (see Milgrom 1990:149). Just as the Levites sacrificed their rights to an inheritance of a territory in the Promised Land, the Israelites were expected to sacrifice a tenth of their earnings for the Levites as a duty. To toy with the tithe

16 Mendelsohn (1956:17-22) argues that Samuel's denunciation of Kingship in 1 Sam. 8:4-17 was informed by the practice of the semi-feudal Canaanite society prior to and during his time. Samuel believed that the monarchical movement of that period would jeopardize the theocratic ideals of Israel as a nation. This evidence from Ugarit lends credence to the understanding of the Old Testament. 
was to toy with God's inheritance that was reserved for the tribe that served God (Lev. 27:30; Num 18:20, 21). Similarly, in the Baal cycle (KTU 1.119:26-35//RS 24.266; Olmo Lete 1999:304,305), if the tithe is not offered, Baal would not repel the enemy's attack on the people.

Tithing appeared in Lev. 27:30-33 in the context of votive offerings. Just as a vow is regarded as a debt to God which must be paid, tithes were also seen as a debt that must be paid. Since the tithes are already owed (because every tithe belongs to the Lord -27.30 ) they cannot be made the object of a special vow. So, Leviticus places tithes in the list of the things one owes to the Lord, and not as a votive offering. ${ }^{17}$ John E Hartley (1992:487) stated that Jewish law stipulated that a person might not vow anything that already belonged to God by reason of another law. Milgrom (2001:2433) reminds us that tithes were the Levites' wages or reward for their life-threatening risks in protecting the sanctuary against encroachment. They were receiving wages commensurate with their precarious service, not gifts for fulfilling covenantal obligations (Num 18). But, in paying the tithes to the Levites, the Israelites were both fulfilling their covenantal obligations and paying for the services rendered to them by the Levites and priests. ${ }^{18}$

Through tithing, Israel's economics became a channel of expressing love to God and love to neighbours, which is at the heart of the Torah. Deuteronomy highlighted the joy and fellowship of presenting the tithe in a family context (Deut 14:26). So the tithe demanded that the people serve their God at a significant cost to themselves regardless of the inconvenience.

\section{Conclusion: The Implications for the African Church}

One may not find a specific parallel to tithing in African Tradition and culture, but the idea of supporting the cult as a theological obligation and with a substantial impost is known to the African in his religion. North (1997:404) reports that a stele found at Naukratis in Egypt, dating from the first year of Nectanebo 1 (380 BCE), decrees that the temple of Neith of Sais is to receive a tithe of the port's turnover and of goods produced. Miriam Lichtheim (2002:130-134) presented a report on a text which probably was a work of the Ptolemaic period referred to as the "Famine Stela" which portrays the king of Egypt issuing decrees for the collection of tithes for the temple of Kahnum as a sign of gratitude to the deity who had promised him an end to the famine in the land. EI Ifesieh (1989:256) informs us that in Igboland (Nigeria), gifts are presented to God in form of sacrifices and offerings. The priests, who receive these gifts, offer a token to the gods, and feed from the rest. Among the Ohafia-Igbo, during the annual festivals, like New Yam festival, families are expected to offer an aspect of their agricultural produce for communal meal in their compound shrines. The community believes that the gifts, sacrifices and communal meals would appease the gods, and guarantee a fruitful harvest the following year. There is no clear cut numerical evaluation like the tithes, but the worshippers see the sacrifices and offerings as a theological obligation.

17 Nowhere in the Old Testament are vows represented as anything other than personal, voluntary promises made to God. We cannot find the practice urged, recommended, or mandated anywhere in the Old Testament. Nevertheless, given the religious impulse of persons to make vows, the writer of Leviticus used the occasion as an opportunity to educate individuals in the legitimate bounds within which vows might be used. Thus, Deut. 23.22 and Ecclesiastes 5.5-6 remind us that persons are not sinning if they refuse to make a vow. But it is not so with tithes. An Israelite would be sinning against God, if he refuses to pay the tithes from the produce of the land, and from the herds and the flocks (Lev. 27.30-33).

18 Apostle Paul had a similar opinion: "Those who are taught the word must share in all good things with their teacher" (Gal. 6:6). 
Perhaps, the reason why most mainline churches in Africa find it difficult to fund their programmes is because the missionaries who brought their churches did not involve them in funding the church projects at the beginning. So their members did not realise the theological obligation on them to uphold the church materially. They felt that the church was a place to receive and not a place to give. But if it was in their traditional religions, they would have known that everyone was expected to contribute materially or else face the wrath of the gods. Just as the ancient Israel's religious institutions and nationalism survived because of their deep-rooted theological convictions without depending on external aids, the African tradition and culture was self reliant.

In the Old Testament, the greatest motivation for the payment of tithe was the belief that God is the sovereign owner of land, and everything one has. In Ohafia-Igbo, the adage, "Onye ji Ji, jiri Nmaa" (The one who holds the yam and the knife) gives an insight to their belief in the sovereignty of God. They offer regular/annual sacrifices and offerings to the "Big God" (Chuku) as the sovereign owner of life and possessions. Church leaders and theologians in Africa should realize that the African is already blessed with this rich ideology that God is the sovereign owner of everything and deserves sacrifices and offerings. According to JS Mbiti:

Sacrifices and offerings constitute one of the commonest acts of worship among African peoples. [...] In some cases, sacrifices and offerings are directed to one or more of the following: God, spirits and living-dead. Recipients in the second and third categories are regarded as intermediaries between God and men, so that God is the ultimate Recipient whether or not the worshippers are aware of that. [...] Four main theories have been advanced to explain the function and meaning of sacrifices and offerings. They are the gift theory, the propitiation theory, the communion theory and the thank-offering theory (Mbiti 1990:58-59).

In a sacrifice, something valuable to the worshipper is forfeited. So was the tithe in the Old Testament. One of the secrets of the progress of some of the African Independent churches today is the sacrificial giving embraced by their members in the form of tithing. Some of them have achieved in less than 20 years, what many mainline churches have not achieved in over 150 years of existence. Until the mainline churches begin to see tithing as one of the sacrifices they are to make for the course of the gospel, funding major projects and missions may still be an illusion.

The Old Testament was an agrarian, subsistence economy. Most African communities are the same. Tithing is an appeal to work. The ancient Israelites were workers, so they tithed from the fruit of their labours. The African should be a worker and not a beggar. Margaret Aringo (2001:172) reports, "According to African tradition, work creates selfsatisfaction, respect, prestige, acceptance and wealth. All normal persons are expected to work. Laziness is not accepted. There is no dirty work and there is no work below human dignity." So the modern African church should challenge their members to appreciate the importance of work whether in subsistence farming or in mechanized/industrialized dimensions, as far as it is possible. In Aringo's words, "People are to direct their skills towards self-employment where salaried jobs fail, and find joy in their task" (2001:173). Also, Emmanuel Martey said:

It is only when Africa is economically independent and interdependent that other races can give black Africans the respect that is due to them in a world where independence is governed by availability of capital. (Martey 1993:143)

The religious community in Pentateuch had a special responsibility towards the Sanctuary, the cult staff and the poor; this experience is not strange to African communities. It is said, 
"Any system that does not explicitly extend protection to the poor will stand condemned from a religious perspectives" (Bosman HL et. al (eds) 1991:255). Most African churches are struggling to pay salaries of church workers and build worship places, how much more care for the poor in their midst because their members are not committing their resources sacrificially. If members would tithe their earnings to the church as the Pentateuch believing community was instructed, care for the poor, the church workers and Sanctuary would not be a problem. In the Pentateuch no one was exempted from tithing; the rich and the poor were included. A similar experience is found in African tradition. In Ohafia-Igbo, the proverb, "Madu anighi atu anya isi utara ebe otughigi ji" (People do not expect to feed from where they have not contributed to. Or, you do not reap from where you did not sow), suggests that everyone is expected to contribute to the communal good no matter how small either in kind or cash. It is one's value system that determines one's responsibilities.

In the Pentateuch, tithe was seen as a participation in God's blessings (Deut 14:29). The people who obeyed God in the Old Testament were blessed and they acknowledged it (2 Chron 31:10; Mal 3:10-12). The African church leaders should educate their people that tithing does not impoverish any one, instead, it gives one an opportunity to participate in God's programmes and blessings. GF Hawthorne told us that tithing was viewed as God's way of involving God's people, in God's own redemptive activity, in God's own immense concern for the poor and destitute. Just as God had shared God's blessings with God's people, those who received them must share with people less fortunate (NIDNTT 1986:853).

In summing up our discussion of tithing in Ugarit and the Pentateuch, and the possible implications for Africa, it has been shown that the practice of tithing was not peculiar to ancient Israel. Similar features were identified with some variations from the practice, the major point of departure being the theological motivation; so the concepts differed. The Ugarit village existed for the king's benefit. They were subjected to debt-slavery or becoming fugitives, deprived culturally, technologically and excluded from any political decisions, thereby the king losing their support in time of war. The texts from Pentateuch revealed that tithing was theologically motivated, which benefited ancient Israel economically, socially and politically. Theologically, the Israelites were to tithe all the wealth of the land that the Lord gave them as a means of submitting to the sovereignty of the Lord as the owner of the land. The tithe was both an expression of worship and a sacrifice of praise to God, the sovereign owner of the land. Economically, in contrast to other forms of offerings and sacrifices, tithing provided the most quantifiable measure of impost for the cult and its personnel. Socially, tithing became a channel of expressing love to God and love to neighbours by caring for the stranger, the orphan and the widow, which is at the heart of the Torah. Politically, the theocratic ideal of ancient Israel's nationalism was strengthened because the custodians of the cult were devoted to their service. The same theological motivation is paramount to building a self-supporting and a self-propagating Church in Africa. Church leaders and theologians in Africa should consider this concept afresh. 


\section{BIBLIOGRAPHY}

Anderson, GA 1987. Sacrifices and offerings in ancient Israel: Studies in their social and political importance. Atlanta, Ga.: Scholars Press.

Aringo, M 2001. "Work in the Old Testament and in African Tradition: Implications for Today," in Mary Getui, et al (eds.) 2001. Interpreting the Old Testament in Africa. New York: Peterlang.

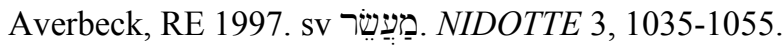

Baumgarten, JM 1984. "On the non-literal use of ma aser/dekate." JBL 103, 245-251.

Bosman, HL, Gous, IGP \& Spangenberg, IJJ (eds.) 1991. Plutocrats and Paupers: Wealth and Poverty in the Old Testament. Pretoria: JL Van Schaik.

Carpenter, EE 1988. sv 'Tithe'. ISBE 4, 861-864.

Dahood, MJ 2003. sv 'Ugarit'. NCE 14, 266-267.

Fisher, LR (ed.) 1975. Ras Shamra Parallels: The Texts from Ugarit and the Hebrew Bible 2. Roma: Pontificum Institutum Biblicum.

Guthrie, HH 1962. sv 'Tithe'. IDB, 654-655.

Hallo, WW 2002. sv 'Royal Land Grant'. COS III, 258

Hartley, JE 1992. Leviticus (Word Biblical Commentary, vol 4). Dallas: Word Books.

Hawthorne, GF 1986. sv 'Tithe'. NIDNTT 3, 851-855.

Heltzer, M 2002. sv 'The Tithe in Ugarit'. COS III, 201-202.

Ifesieh, EI 1989. Religion at the Grassroots: Studies in Igbo Religion. Enugu: Fourth Dimension.

Jagersma, H 1981. "The tithes in the Old Testament," in Albrektson, B, et al (eds.), Remembering all the way... A collection of Old Testament studies published. Leiden: Brill, 116-128.

Lichtheim, M 2002. sv 'Famine stella'. COS III, 130-134.

Liverani, M 1988. sv 'Ugarit'. ISBE 4, 937-941.

Martey, E 1993. African Theology: Inculturation and Liberation. New York: Orbis Books.

Mbiti, JS 1990. African religions and philosophy ( $2^{\text {nd }}$ ed). Oxford: Heinemann.

McConville, JG 1984. Law and theology in Deuteronomy. Sheffield, England: JSOT.

Mendelsohn, I 1956. "Samuel's denunciation of kingship in the light of the Akkadian document from Ugarit." BASOR 143, 17-22.

Milgrom, J 1990. Numbers (JPS Commentary, vol 4). Philadelphia: Jewish Publication Society of America.

Milgrom, J 2001. Leviticus 23-27: A New Translation with Introduction and Commentary (The Anchor Bible). New York: Doubleday.

North, R 2001. sv עֶׁשׁ. TDOT ix, 404-409.

Olmo Lete, GD 1999. Canaanite Religion according to the Liturgical Texts of Ugarit. Bethesda: CDL.

Pardee, D \& Yon, M 1992. sv 'Ugarit'. ABD vi, 695-720.

Sankore, R 2005. "What are the NGOs doing?" New African Aug/Sept, p15.

Sarna, NM 1989. Genesis (JPS Commentary, vol 1). Philadelphia: Jewish Publication Society of America.

Watson, GE \& Wyatt, N (eds.) 1999. Handbook of Ugaritic Studies. Leiden: Brill.

Weinfeld, M 1970. "The covenant of grant in the Old Testament and in the Ancient Near East.” JAOS 90, 184-203. 
Weinfeld, M 1971. sv 'Tithes'. EJ 15, 1155-1163.

Wellhausen, J (1844-1918) 1994. Prolegomena to the history of Israel. With a reprint of the article Israel from the Encyclopaedia Britannica. Atlanta: Scholars.

Wenham, GJ 1987. Genesis 1-15 (Word Biblical Commentary, vol 1). Waco: Word Books.

Westermann, C 1981. Genesis 12-36. London: SPCK.

\section{Abbreviations}

ABD Anchor Bible Dictionary

BASOR Bulletin of the American School of Oriental Research. New Haven.

COS Hallo, WW 2002. Context of Scripture I-III. Leiden: Brill

EJ Wischnitzer, M (ed.) 1971. Encyclopaedia Judaica 15. Jerusalem: Keter Publishing House.

IDB Buttrick, GA (ed.) 1962. The Interpreter's Dictionary of the Bible. New York: Abingdon

ISBE Bromiley, GW et al (eds.) 1988. The International Standard Bible Encyclopedia. Grand Rapids: WB Eerdmans.

JAOS Journal of the American Oriental Society. Boston/New Haven.

JBL Journal of Biblical Literature. Philadelphia.

KTU Dietrich, M; Loretz, O \& Sanmartin, J 1976. The Cuneiform Alphabetic Texts from Ugarit, Ras Ibn Hani and other places. $2^{\text {nd }}$, Enlarged edition. Neukirchen.

NCE New Catholic Encyclopedia 14. $2^{\text {nd }}$ Ed. Detroit:Gale (2003).

NIDNTT Brown, C 1986. New International Dictionary of New Testament Theology. Grand Rapids, MI.: Zondervan Publishing House

NIDOTTE Vangemeren, WA (ed.) 1997. New International Dictionary of Old Testament Theology and Exegesis. Grand Rapids, MI.: Zondervan Publishing House.

PRU Schaeffer, CF 1957. La palais royal d'Ugarit. Paris: Klincksieck.

TDOT Botterweck, GJ and Ringgren, H 2001. Theological dictionary of the Old Testament. Grand Rapids: Eerdmans. 